\title{
Effect of Organic Manures and Inorganic Fertilizers on Growth and Yield of Turnip (Brassica rapa L.) in Prayagraj Region
}

\author{
Suma Gracia Pamula* and Anita kerketta \\ Department of Horticulture, Naini Agricultural Institute, SHUATS, \\ Prayagraj Allahabad, U.P., India \\ *Corresponding author
}

\section{A B S T R A C T}

\begin{tabular}{|c|}
\hline Keywords \\
\hline $\begin{array}{l}\text { NPK, FYM, } \\
\text { Vermicompost, } \\
\text { Poultry Manure, } \\
\text { Growth, Yield and } \\
\text { Turnip }\end{array}$ \\
\hline Article Info \\
\hline $\begin{array}{l}\text { Accepted: } \\
08 \text { December } 2020 \\
\text { Available Online: } \\
10 \text { January } 2021\end{array}$ \\
\hline
\end{tabular}

A field experiment entitled "Effect of organic manures and inorganic fertilizers on growth, yield of Turnip (Brassica rapal.)" was carried out at research field, Department of Horticulture, Naini Agriculture Institute, Sam Higginbottom University of Agriculture, Technology and Sciences, Prayagraj, during the Rabi season of (2019-2020). Five plants were selected randomly from each plot and were tagged and maintained as observational plants for recording their growth and yield characters of turnip. The Experiment was laid out in a Randomized Block Design with 11 treatments and 3 replications. Results revealed that the application of $\mathrm{T}_{10}: 25 \%$ RDN $(20: 12.5: 12.5)+75 \% \mathrm{PM}\left(7.5 \mathrm{t} \mathrm{ha}^{-1}\right)$ influenced most of the characteristics significantly and recorded the highest values of plant height $(46.74 \mathrm{~cm})$, number of leaves per plant $(22.30)$, leaf length $(\mathrm{cm})(30.23)$, shoot weight $(23.87 \mathrm{~g})$, root weight $(117.48 \mathrm{~g})$, root length $(5.61 \mathrm{~cm})$, root diameter $(6.67 \mathrm{~cm})$, root yield per plot $\left(14.92 \mathrm{~kg}^{-1}\right)$ and root yield $(355.17 \mathrm{q} / \mathrm{ha})$.

\section{Introduction}

Turnip (Brassica rapaL.), $2 \mathrm{n}=20$ belongs to family Cruciferae/ Brassicaceae. It is a winter crop but also a popular root vegetable crop. it is botanically herb, but is cultivated as annual root crop for both human and animal consumption. The storage organ is swollen hypocotyl. Turnips are high in Vitamin $\mathrm{C}$, Calcium, Iron and other minerals, the tops (turnip greens) can be used as green vegetable which have high levels of Vitamin A, B, but the crop is generally grown for its roots. The nutritive value for $100 \mathrm{~g}$ of edible turnip root has Moisture $91.6 \mathrm{~g}$, Protein $0.5 \mathrm{~g}$, Fat $0.2 \mathrm{~g}$, Minerals 0.6 g, Fibre 0.9 g, Carbohydrates 6.2 g, Energy 29 K Cal, Calcium $30 \mathrm{mg}$, Phosphorous $40 \mathrm{mg}$, Iron $0.4 \mathrm{~g}$, Thiamine 0.04 g, Riboflavin $0.04 \mathrm{~g}$, Niacin $0.5 \mathrm{mg}$, Vitamin C $43 \mathrm{mg}$, whereas., in leaves of turnip has Moisture $81.6 \mathrm{~g}$, Protein $4.0 \mathrm{~g}$, Fat $1.5 \mathrm{~g}$, Minerals $2.2 \mathrm{~g}$, Fibre1.0 g, Carbohydrates 9.4 g, Energy $67 \mathrm{~K} \mathrm{Cal,} \mathrm{Calcium} 710 \mathrm{mg}$, Phosphorous $60 \mathrm{mg}$, Iron $28.4 \mathrm{mg}$, Carotene

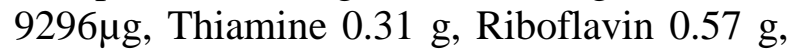
Niacin $5.4 \mathrm{mg}$, Vitamin C $180 \mathrm{mg}$. India is the world's second largest producer of vegetables next to China. According to 
estimation, India produces 87.50 million tonnes of vegetables from an area of 5.80 million hectares. Thus, India shares about $12 \%$ of world's output of vegetables (Thamburaj and Singh, 2001). In India, turnip is cultivated in an area of 2500 hectares with an annual production of 50,000 tonnes.

The organics are the indigenous source of nutrients which can help in increasing production and productivity along with improvement in soil physical conditions. Use of such organic materials, which are being wasted in large amounts without proper use can help in reducing cost of cultivation, increasing productivity and improving soil as well as human and livestock health. Various organic manures so far recognized in this group are green manures, rural/urban compost, farm yard manure, vermicompost, liquid organic manure etc.,

In India, all the organic manures together have a potential to supply approximately 33 million tonnes of N,P,K per year (Gaur et al., 1992). Among organic manures, vermicompost is wieldy accepted by farmers and is produced due to the activity of earthworms. It is rich in all plant nutrients, beneficial microorganisms like $\mathrm{N}$-fixers, biologically active metabolites, particularly gibberellins, cytokinins, auxins and group B vitamins and several enzymes like lipase, cellulose, chitase, urease, dehydrogenase and nitrogenase (Bano et al., 1987). The vermicompost can be applied alone or in combination with inorganic fertilizers to get better yield and quality of diverse crops.

\section{Materials and Methods}

The present experiment effect of organic manures and inorganic fertilizers on growth and yield of turnip (Brassica rapaL.) was donein Horticulture research field, Department of Horticulture, Naini Agriculture
Institute, SHUATS, Prayagraj region was conducted during the year 2019-2020. The variety used for the experiment is purple top white globe, which were collected from local Prayagraj market. The observations were recorded on five randomly selected plants per replication was conducted in Randomized block design (RBD) with 10 treatments and 3 replications $\quad \mathrm{T}_{0} \quad$ Control, $\mathrm{T}_{1} 100 \%$ Recommended dose of nutrient $(80: 50: 50)+25$ $\mathrm{t} \mathrm{ha}^{-1}, \mathrm{~T}_{2:}: 75 \%$ RDN (60:37.5:37.5) +25\% FYM (6.25 $\left.\mathrm{t} \mathrm{ha}^{-1}\right), \mathrm{T}_{3}: 50 \%$ RDN (40:25:25) $+50 \%$ FYM (12.5 $\left.\mathrm{t} \mathrm{ha}^{-1}\right), \mathrm{T}_{4}: 25 \%$ RDN $(20: 12.5: 12.5)+75 \%$ FYM (18.75 $\left.\mathrm{t} \mathrm{ha}^{-1}\right)$, $\mathrm{T}_{5}: 75 \% \quad \mathrm{RDN} \quad(60: 37.5 .5: 37.5) \quad+25 \%$ Vermicompost $\left(1.5 \mathrm{t} \mathrm{ha}^{-1}\right), \mathrm{T}_{6:} 50 \% \mathrm{RDN}$ $(40: 25: 25)+50 \%$ Vermicompost $\left(3 \mathrm{t} \mathrm{ha}^{-1}\right)$, $\mathrm{T}_{7}: 25 \% \quad \mathrm{RDN} \quad(20: 12.5: 12.5) \quad+75 \%$ Vermicompost (4.5 $\left.\mathrm{t} \mathrm{ha}^{-1}\right) \mathrm{T}_{8:} 75 \% \mathrm{RDN}$ $(60: 37.5: 37.5)+25 \%$ PM $\left(2.5 \mathrm{t} \mathrm{ha}^{-1}\right), \mathrm{T}_{9:} 50 \%$ $\operatorname{RDN}(40: 25: 25)+50 \%$ PM (5 t ha $\left.{ }^{-1}\right), \mathrm{T}_{10}$ : $25 \%$ RDN (20:12.5:12.5) +75\% PM (7.5 tha $\left.{ }^{1}\right)$. The data collected on different parameters during the course of investigation were subjected to statistical analysis as per method of analysis of variance (Panse and Sukhatme 1957). The significance and non - significance of the treatment effect was judged with the help of ' $F$ ' variance ratio test. Calculated ' $F$ ' value was compared with the table value of ' $F$ ' at $5 \%$ level of significance. If calculated value exceeds the table value, the effect was considered to be significant. The significant differences between the means were tested critical differences at $5 \%$ level of significance.

\section{Results and Discussion}

The detail pertaining to the research finding were presented and summarized below in this chapter. Organic manures and inorganic fertilizer were given at 25, 35 And 45 days after sowing. The results of present investigation are as follow and presented in table 01 . 
Table.1 Performance of Organic manures and inorganic fertilizers on growth and yield attributes of Turnip

\begin{tabular}{|c|c|c|c|c|c|c|c|c|c|c|}
\hline $\begin{array}{l}\text { Treatment } \\
\text { Symbol }\end{array}$ & Treatment combination & $\begin{array}{c}\text { Plant } \\
\text { height } \\
60 \text { DAS }\end{array}$ & $\begin{array}{c}\text { No.of } \\
\text { leaves } \\
60 \text { DAS }\end{array}$ & $\begin{array}{c}\text { Leaf } \\
\text { length } \\
\text { (cm) }\end{array}$ & $\begin{array}{l}\text { Shoot } \\
\text { weight } \\
\text { (g) }\end{array}$ & $\begin{array}{c}\text { Root } \\
\text { weight } \\
\text { (g) }\end{array}$ & $\begin{array}{c}\text { Root } \\
\text { length } \\
(\mathrm{cm})\end{array}$ & $\begin{array}{c}\text { Root } \\
\text { diameter } \\
\text { (cm) }\end{array}$ & $\begin{array}{l}\text { Root yield } \\
\text { per plot } \\
\text { (kg) } 4 \mathrm{~m}^{2}\end{array}$ & $\begin{array}{l}\text { Root } \\
\text { yield } \\
\text { (q/ha) }\end{array}$ \\
\hline $\mathbf{T}_{\mathbf{0}}$ & Control & 38.57 & 13.56 & 20.42 & 18.81 & 84.11 & 5.61 & 4.82 & 11.19 & 166.36 \\
\hline $\mathbf{T}_{1}$ & $100 \%$ Recommended dose of nutrient $(80: 50: 50)$ & 39.51 & 16.64 & 25.56 & 22.19 & 96.40 & 6.73 & 6.02 & 12.82 & 305.27 \\
\hline $\mathbf{T}_{2}$ & $75 \%$ RDN $(60: 37.5: 37.5)+25 \%$ FYM $\left(6.25 \mathrm{t} \mathrm{ha}^{-1}\right)$ & 41.50 & 18.51 & 25.44 & 22.02 & 95.67 & 6.16 & 5.56 & 12.72 & 302.94 \\
\hline $\mathbf{T}_{3}$ & $50 \%$ RDN $(40: 25: 25)+50 \%$ FYM $\left(12.5 \mathrm{t} \mathrm{ha}^{-1}\right)$ & 42.46 & 17.42 & 26.44 & 20.12 & 104.01 & 7.10 & 5.63 & 13.85 & 329.82 \\
\hline $\mathbf{T}_{4}$ & $25 \%$ RDN (20:12.5:12.5) +75\% FYM (18.75 $\left.\mathrm{t} \mathrm{ha}^{-1}\right)$ & 41.63 & 19.53 & 21.52 & 21.31 & 111.81 & 6.62 & 5.57 & 14.31 & 335.07 \\
\hline $\mathbf{T}_{5}$ & $75 \%$ RDN $(60: 37.5 .5: 37.5)+25 \%$ VC $\left(1.5 \mathrm{t} \mathrm{ha}^{-1}\right)$ & 40.45 & 19.58 & 23.49 & 21.63 & 116.10 & 7.39 & 5.76 & 14.14 & 338.08 \\
\hline $\mathbf{T}_{6}$ & $50 \%$ RDN $(40: 25: 25)+50 \%{ }^{\prime} \mathrm{VC}\left(3 \mathrm{t} \mathrm{ha}^{-1}\right)$ & 41.52 & 20.22 & 24.50 & 21.34 & 114.22 & 6.84 & 5.59 & 14.07 & 340.76 \\
\hline $\mathbf{T}_{7}$ & $25 \%$ RDN $(20: 12.5: 12.5)+75 \%$ VC $\left(4.5 \mathrm{t} \mathrm{ha}^{-1}\right)$ & 38.57 & 19.20 & 23.52 & 23.07 & 113.44 & 7.34 & 5.65 & 14.20 & 336.61 \\
\hline $\mathbf{T}_{8}$ & $75 \%$ RDN $(60: 37.5: 37.5)+25 \%$ PM $\left(2.5 \mathrm{t} \mathrm{ha}^{-1}\right)$ & 43.11 & 20.49 & 27.33 & 23.45 & 116.61 & 7.55 & 6.11 & 14.43 & 343.50 \\
\hline $\mathbf{T}_{9}$ & $50 \%$ RDN $(40: 25: 25)+50 \%$ PM $\left(5 \mathrm{t} \mathrm{ha}^{-1}\right)$ & 43.41 & 21.53 & 28.43 & 23.69 & 117.43 & 7.66 & 6.21 & 14.48 & 344.83 \\
\hline $\mathbf{T}_{10}$ & $25 \%$ RDN $(20: 12.5: 12.5)+75 \%$ PM $\left(7.5 \mathrm{t} \mathrm{ha}^{-1}\right)$ & 46.74 & 22.30 & 30.23 & 23.87 & 117.48 & 8.15 & 6.67 & 14.92 & 355.17 \\
\hline \multicolumn{2}{|r|}{ F-Test } & $\mathrm{S}$ & $\mathrm{S}$ & $\mathrm{S}$ & S & $\mathbf{S}$ & $\mathbf{S}$ & $\mathbf{S}$ & $\mathbf{S}$ & $\mathrm{S}$ \\
\hline \multicolumn{2}{|r|}{ S.Ed. (+) } & 0.197 & 0.188 & 0.122 & 1.260 & 1.842 & 0.279 & 0.214 & 0.445 & 10.843 \\
\hline \multicolumn{2}{|r|}{ C. D. at 0.5} & 0.412 & 0.392 & 0.254 & 2.628 & 3.842 & 0.582 & 0.446 & 0.950 & 22.619 \\
\hline
\end{tabular}


The maximum plant height (46.74) was observed in the treatment $\mathrm{T}_{10}: 25 \% \mathrm{RDN}$ (20:12.5:12.575\% PM (7.5 $\left.\mathrm{t} \mathrm{ha}^{-1}\right)$ and the minimum plant height (38.57) was observed in Treatment $\mathrm{T}_{0 \text { : }}$ (control). The maximum leaf length $(\mathrm{cm})$ (30.23) was observed in the treatment $\mathrm{T}_{10}: 25 \%$ RDN $(20: 12.5: 12.5)+75 \%$ PM (7.5 t ha $\left.{ }^{-1}\right)$ and the minimum leaf length (20.42) was observed in Treatment $\mathrm{T}_{0}$ (control).The highest shoot weight was found in treatment (23.87) and other treatments found next in order in this regard as $\mathrm{T}_{10}: 25 \%$ RDN (20:12.5:12.5) +75\% PM (7.5 $\left.\mathrm{t} \mathrm{ha}^{-1}\right)$ and the lowest shoot weight was found in treatment $\mathrm{T}_{0}(18.81 \mathrm{~g})$ control. The highest root weight was found in treatment $\mathrm{T}_{10}: 25 \%$ RDN (20:12.5:12.5) +75\% PM (7.5 $\left.\mathrm{t} \mathrm{ha}^{-1}\right)$ (117.48) and the lowest root weight was found in treatment $\mathrm{T}_{0}:(84.11)$ control. The highest root length was found in treatment $\mathrm{T}_{10}: 25 \%$ RDN (20:12.5:12.5) +75\% PM (7.5 t $\left.\mathrm{ha}^{-1}\right)$ (5.61) and the lowest root length was found in treatment $\mathrm{T}_{0 \text { : }}$ (5.61) control. The highest root diameter was found in treatment $\mathrm{T}_{10}: 25 \%$ RDN (20:12.5:12.5) +75\% PM (7.5 t $\left.\mathrm{ha}^{-1}\right)$ (6.67) and the lowest root diameter was found in treatment $T_{0:}(4.82)$ control. Highest root yield per plot $(\mathrm{kg})$ was recorded in treatment $\mathrm{T}_{10}: 25 \%$ RDN (20:12.5:12.5)+75\% PM (7.5 $\left.\mathrm{t} \mathrm{ha}^{-1}\right)\left(14.92 \mathrm{~kg}^{-1}\right)$ and the and minimum root yield per plot was obtained in treatment $\mathrm{T}_{0}$ :control $\left(11.19 \mathrm{~kg}^{-1}\right)$. Highest root yield $(355.17 \mathrm{q} / \mathrm{ha})$ was recorded in treatment $\mathrm{T}_{10}: 25 \%$ RDN (20:12.5:12.5) +75\% PM (7.5 t $\mathrm{ha}^{-1}$ ) and minimum root yield per plot was obtained in treatment $\mathrm{T}_{0}$ : control $(266.36 \mathrm{q} / \mathrm{ha})$

On the basis of present investigation it is concluded that the treatment $\mathrm{T}_{10}: 25 \%$ RDN $(20: 12.5: 12.5)+75 \%$ PM $\left(7.5 \mathrm{t} \mathrm{ha}^{-1}\right)$ was found to be the best treatment combination in respect of plant growth and root yield parameter of turnip grown under Prayagraj Agro-climatic conditions. The treatment $\mathrm{T}_{8}: 75 \%$ RDN (60:37.5:37.5) +25\% PM (2.5 t $\left.\mathrm{ha}^{-1}\right)$, showed maximum gross return, net return and benefit: cost ratio i.e. (1: 2.53) respectively. These finding are based on one season trail, therefore, further evaluation trails are needed to substantiate the findings.

\section{References}

Bano, K. and Kale, R. D.,1991,Earthworm fauna of Southern Karnataka, India. In: Advances in Management and Conservation of Soil Fauna. (Eds. G.K. Veeresh; D. Rajagopal and C. A.Viraktamath), Oxford and IBH, New Delhi. pp. 627-634.Byline M. Kiran, M.S. Jilani and K. Waseem (2017).Impact of different organic manures and npkapplication on the growth and yield of turnip (Brassica rapa L).Pakistan Journal of Science 30, 2017

Byline M. Kiran, M.S. Jilani and K. Waseem (2017).Impact of different organic manures and npk application on the growth and yield of turnip (Brassica rapa 1).Pakistan J. of Science 30, 2017

Chitti Jagadeesh, M. Madhavi, M. Siva Prasad and V.V. Padmaja (2018). Effect of Organic Manures on Growth and Yield attributes of BeetRoot $\mathrm{Cv}$. Crimson Globe.

Int.J.Curr.Microbiol.App.Sci(2018) 7(11): 3538-3553

Fatemeh Etemadi and Mahya Ansari (2017). Effect of parental nutrient management on seed germinability of turnip. Int. J. Adv. Res. 4(9), 2011-2017

Gaur AC, Neelkanthan S and Dargan KS. (1990). Livestock and human wastescharacteristic and manurial value. In: Organic Manures, Pub. ICAR, pp. 13-95.

Ghimire Sunil, Bishownath Adhikari, Sapana Pandey, KashikaBelbase, Sandhya Lamichhane and Rukmagat Pathak (2020). "Effect of Different Organic Manure on Growth and Yield of Radish 
in Deukhuri, Dang, Nepal". Acta Scientific Agriculture4.3 (2020): 01-05. Indikumari T. Devi, Haripriya K. and Rajeswari R. (2016). Effect of organic nutrients and biostimulants on yield characters of beetroot (beta vulgaris 1.). Plant Archives Vol. 16 No. 1, 2016 pp. 399-402

Irene P. Vethamoni and Kayalvizhi (2018). Effect of fertigation on growth and yield of beetroot (Beta vulgaris L.) under shade net condition. International Journal of Chemical Studies 2018; 6(4): 176-178 3

Kadam VD, Shinde SJ and Satav DC (2018). Effect of different spacing and fertilizer levels on yield and economics of beetroot (Beta vulgaris L.). Journal of Pharmacognosy and Phytochemistry 2018; 7(6): 31-35

Nawaz, M.Q., K. Ahmed, G. Qadir, M. Rizwan, M.F. Nawaz and M. Sarfraz. (2020). Growth and yield of turnip (Brassica rapa L.) in response to different sowing methods and nitrogen levels in salt-affected soils. Pakistan $J$. of Agri. Res., 33(1): 126-134.

Panse, V. G. and Sukhatme,P.V. (1957), Statistical Methods for Agricultural Workers $\left(2^{\text {nd }} E d n\right.$.), Indian Council of Agriculture Research, New Delhi,381p.
S.K.Singh, R.B.Yadav, Jagadish Singh and Bijendra Singh, Dr. B.SinghOrganic farming in vegetable crops, Indian institute of vegetable research, Varanasi.

S.Thamburaj and Narendra Singh (2001), Textbook of vegetables tuber crops and spicesIndian council of agricultural research

Sadia A.A., Ona A.F., Taufique T., Mehraj H. and Jamal A.F.M. Uddin (2013). Influence of nitrogen on growth and yield of turnip. J. Expt. Biosci. 4(2):3942, July 2013

Shafeek M.R., Asmaa R. Mahmoud, Aisha H. Ali, Magda M. Hafez and S.M. Singer (2015). Effect of different levels of potassium applied with foliar spraying of yeast on growth, yield and root quality of turnip under sandy soil conditions.

Int.J.Curr.Microbiol.App.Sci

(2015) 4(10): 868-877

Yanthan,T.S.;Singh,V.B.;Kanaujia,S.P.;Singh ,A.K. (2012).Effect of integrated nutrient management on growth, yield and nutrient uptake by turnip (Brassica rapa L.) cv. Pusasweti and their economics. J.l of Soils and Crops 2012 Vol.22 No.1 pp.1-9 ref.11.

\section{How to cite this article:}

Suma Gracia Pamula and Anita kerketta. 2021. Effect of Organic Manures and Inorganic Fertilizers on Growth and Yield of Turnip (Brassica rapa L.) in Prayagraj Region. Int.J.Curr.Microbiol.App.Sci. 10(01): 560-564. doi: https://doi.org/10.20546/ijcmas.2021.1001.068 